\title{
Phenology and biomass distribution pattern in two varieties of common bean (Phaseolus vulgaris L.)
}

\author{
Fenología y patrones de distribución de biomasa en dos variedades de frijol \\ (Phaseolus vulgaris L.)
}

NERI-LUNA, Cecilia †*, VILLARREAL-RUIZ, Luis ${ }^{2}$, HUERTA-MARTÍNEZ, Francisco Martín ${ }^{1}$ and MUÑOZ-URIAS Alejandro ${ }^{1}$

\begin{abstract}
${ }^{1}$ Laboratorio de Ecofisiología Vegetal, Departamento de Ecología, CUCBA, Universidad de Guadalajara, Camino Ing. Ramón Padilla Sánchez No. 2100, Zapopan, Jalisco, México. C.P. 45110

${ }^{2}$ Laboratorio de Recursos Genéticos Microbianos \& Biotecnología (LARGEMBIO), PREGEP-Genética, Colegio de Postgraduados, Campus Montecillo, Texcoco, Edo. México, México. C.P. 56230
\end{abstract}

ID $1^{\text {st }}$ Author: Cecilia, Neri-Luna / ORC ID: 0000-0002-8941-2305, CVU CONACYT ID: 72630

ID $1^{\text {st }}$ Coauthor: Luis, Villarreal-Ruiz / ORC ID: 0000-0001-8472-4898, CVU CONACYT ID: 51826

ID $2^{\text {nd }}$ Coauthor: Francisco Martín, Huerta-Martínez / ORC ID: 0000-0001-6923-3425, CVU CONACYT ID: 121720

ID $3^{\text {rd }}$ Coauthor: Alejandro, Muñoz-Urias / ORC ID: 0000-0003-0828-9729

DOI: $10.35429 / J N A S .2019 .19 .6 .18 .27$

Received June 21, 2019; Accepted December 30, 2019

\begin{abstract}
In Mexico, bean crop is one of the most important agricultural resources to provide food also for its economic value as product. However, there is a lack of research related with Phaseolus vulgaris varieties, specifically for plants cultivated for human consumption as common bean pods. It was characterized the main phenological events and the biomass distribution in two different varieties "Black Valentine" (BV, green pod) y "Black Wax" (BW, yellow pod) of common bean. For each variety it was chosen 4 plants and every 10 days after planting (DAP) from each organ emerged the fresh and dry weight and the leaf area were recorded. Then, at 7, 14 , 21, 28 and 35 days after anthesis (DAA) the growth, fresh and dry weight and nitrogen content were evaluated from pods $(n=10)$ of each variety of common bean. During the first 30 DAP the dry weight accumulation in both varieties was correlated with leaf area. The beginning of flowering and fruit growth was an important factor in the source-sink relationship. Differences were not noted in the final fresh and dry weight of the pods between "BV" and "BW" varieties.
\end{abstract}

Phaseolus vulgaris, Pods, carbon Partitioning

\begin{abstract}
Resumen
En México, el frijol es un cultivo importante ya que ocupa el segundo lugar como alimento y el cuarto por el valor de su producción. Existen pocos trabajos sobre el desarrollo de variedades de Phaseolus vulgaris cuyos frutos en sus fases inmaduras se consuman como hortalizas (ejotes). Se caracterizó los principales eventos fenológicos, así como los patrones de distribución de biomasa en dos variedades de frijol "Black Valentine" (BV, vaina verde) y "Black Wax" (BW, vaina amarilla). Se tomaron 4 plantas por variedad y cada 10 días después de siembra (DDS), se registró la aparición de cada uno de los distintos órganos diferenciados, así como su peso fresco, seco y área foliar. Se colectaron vainas $(n=10)$ de cada variedad a los $7,14,21,28$ y 35 días después de antesis (DDA) y se registró longitud, peso fresco, seco y contenido de nitrógeno. Los primeros 30 DDS, la tasa de acumulación de materia seca en ambas variedades se relacionó con el incremento del área foliar. El inicio del desarrollo de flores y frutos (36-37 DDS) modificó la relación fuente-demanda (agua, carbono) entre los órganos vegetativos y reproductivos. No se encontró diferencias significativas en el peso fresco y seco final entre las vainas de las variedades "BV" $\mathrm{y}$ "BW".
\end{abstract}

Phaseolus vulgaris, Vainas, Distribución de carbon

Citation: NERI-LUNA, Cecilia, VILLARREAL-RUIZ, Luis, HUERTA-MARTÍNEZ, Francisco Martín and MUÑOZURIAS Alejandro. Phenology and biomass distribution pattern in two varieties of common bean (Phaseolus vulgaris L.). Journal of Natural and Agricultural Sciences. 2019, 6-19: 18-27

*Correspondence to Author (cecilia.neri@academicos.udg.mx)

$\dagger$ Researcher contributing first author 


\section{Introduction}

The genus Phaseolus separated from its closest relatives approximately 1.3 million years ago, its origin and domestication is located in the Americas with two geographical points (Mesoamerica and the Andes) where there is a great diversity of forms, both wild and cultivated ( Miranda, 1990; Lara-Flores, 2015; Wallace et al., 2018). The long period in which the beans have been under domestication, together with the great diversity of ecological conditions that prevail in the different agricultural regions, allowed this species to acquire a very large genetic variability, due to spontaneous mutations, genetic recombination and selection ( Robles (1990)

In particular, Mexico is considered as one of the centers of origin for various types of beans because of the findings made and for finding wild species from the five most cultivated groups of beans: P. vulgaris (common bean), P Acutifolius (Tepari Bean), P. Lunatus (Lima Bean), P. Coccineus (Ayocote or Scarlet Bean), and P. Polyanthus (Annual Bean).

The production regions are mainly located in developing tropical and subtropical areas with a production of 12 million tons (Durigon et al., 2019). World bean production registers an upward trend, driven by increases in cultivated area and average yields per unit area. In seven countries, $63 \%$ of the world crop is concentrated: India, Myanmar, Brazil, United States, Mexico, China and Tanzania.

In our country, beans (Phaseolus vulgaris) is one of the most important agricultural crops, since it occupies the fourth position in importance due to the area it occupies (after corn, grasses and sorghum) and because it is the legume with the highest consumption due to its high protein content (36\% of the daily protein intake) and minerals, either as dry grain and in less quantity for food as fresh seeds and tender pods known as "green beans" (LaraFlores, 2015; FIRA, 2016, Padilla-Chacón et al., 2019).
Currently, there is a tendency to increase the consumption of vegetables in the diet, so an increase in the demand for green beans worldwide is expected, since they are vegetables of high nutritional quality and because of their content of vitamin A, protein, fiber and calcium At a national level, there is a tendency to extend the use of this legume since per capita consumption has increased in recent years from 0.9 to $1.1 \mathrm{~kg}$. (Esquivel-Esquivel et al. 2006). However, currently, the bean bean bean seed is imported from the USA, (with the consequent flight of currencies and the dependence on varieties), which, because it is developed in other environments, has little information about its adaptation in production systems (example: greenhouse) of our country, so it has been suggested to try different varieties of green beans considering different growth habits, flower production, and characteristics of the pod (variety in size, shape and color), in order to generate basic information on the development of varieties that meet the production and quality demanded, as well as with characteristics of the pod that facilitate their harvest (EsquivelEsquivel, 2006; Salinas-Ramírez, 2008; Wallace et al., 2018).

Also, according to Gebeyehu (2019) it is important to understand the correlation between growth parameters and their contribution to productivity in different stages of development in common beans, for this reason the objective of this research is to characterize the main phenological events, as well as the biomass distribution patterns in two varieties of Phaseolus vulgaris L. contrasting in their sheath color.

\section{Methodology}

\section{Vegetal material}

We worked with two varieties of beans: "Black Valentine" (BV, green pods) and "Black Wax" (BW, yellow pods), both with a certain growth habit Type 1 (CIAT, 1982). These varieties have ease of handling in greenhouse conditions, because they are low bearing and short vegetative cycle. The seeds were sown in pots (with a capacity of $4 \mathrm{~L}$ ) per variety. In each of them, a mixture of mountain soil and sand previously disinfected with methyl bromide was placed. During the development of the plants, the temperature ranged between $8-30{ }^{\circ} \mathrm{C}$, with a relative humidity between $30-80 \%$ and it was tried to keep the substrate at field capacity.

NERI-LUNA, Cecilia, VILLARREAL-RUIZ, Luis, HUERTAMARTÍNEZ, Francisco Martín and MUÑOZ-URIAS Alejandro. Phenology and biomass distribution pattern in two varieties of common bean (Phaseolus vulgaris L.). Journal of Natural and Agricultural Sciences. 2019 


\section{Phenology in plants}

To evaluate the vegetative and reproductive development in the plants of both varieties, 4 plants were taken at random by variety and every 10 days after planting (DDS) the appearance of the different organs that differed during the development of the plant was recorded. (stem, leaves, petioles, inflorescences and pods). Also, the following variables were measured:

\section{Foliar area $(A F)$}

It was evaluated from the emergence of the leaves, and was carried out through the destructive method, using an automatic foliar area integrator (Delta-T Devices Meter Area [I]). The measurement was made on the sheets of the leaves that had reached a length greater than 3 $\mathrm{cm}$, not including the petiole.

\section{Determination of fresh and dry weight in plants}

The plants that were obtained in the different samples were taken to the laboratory, where their organs were dissected, recording the fresh weight (PF) of each of them in an analytical balance. This material was then placed in a circulating air oven at a temperature that ranged between $60-70^{\circ} \mathrm{C}$ for approximately 72 hours, until a constant weight was achieved. Dry weight (PS) was determined using an analytical balance. The information obtained allowed to establish the relationship of FP between vegetative and reproductive parts and to calculate the distribution and accumulation of biomass per unit area $\left(\mathrm{m}^{2}\right)$.

\section{Pod growth}

For the evaluation of the growth of the bean pods, all the flowers that were differentiated in the plants were marked. Of those that were transformed into fruits, pods were collected at different time intervals $(7,14,21,28$ and 35 days after anthesis [DDA]). On each of these dates, 10 pods were randomly harvested for each variety, in which their length $(\mathrm{cm})$ was measured from the upper to the lower end of the pod. Then, the pericarp was separated from the seeds and the PF of each of these parts was determined with a precision balance. Next, the structures were placed in a stove a circulating air stove at a temperature that ranged between $60-70{ }^{\circ} \mathrm{C}$ for approximately $72 \mathrm{~h}$, until a constant weight was achieved. The PS was obtained with an analytical balance.

\section{Nitrogen content in pods}

Once the PS of the pods was registered, they were pulverized in a Willey mill, passing the flour through a sieve (no. 60). $100 \mathrm{mg}$ of each sample was obtained from this powder to determine the nitrogen $(\mathrm{N})$ content by means of the microKjeldahl method. To effect digestion, the samples were placed in test tubes and a mixture consisting of $0.5 \mathrm{~g}$ of catalyst and $3 \mathrm{~mL}$ of concentrated $\mathrm{H} 2 \mathrm{SO} 4$ was added; The tubes were then placed in a Block Digester (Technicon model BD-40) under an extraction hood at a temperature close to $300^{\circ} \mathrm{C}$. Digestion was considered finished when the liquid had a transparent color and no residues of carbonized dry matter. Subsequently, the samples were allowed to cool a few minutes before being taken to the distillation apparatus.

Test tubes containing the digested sample were added $0.1 \mathrm{~mL}$ of phenolphthalein and placed in the distillation apparatus; A saturated $\mathrm{NaOH}$ solution was added gradually to each sample until an alkaline reaction was achieved. The distillation was carried out for approximately $25 \mathrm{~min}$, receiving the distillate in an Erlenmeyer flask containing $10 \mathrm{~mL}$ of $\mathrm{H}_{3} \mathrm{BO}_{3}$ (4\%) and 5 drops of the Tashiro indicator. The $\mathrm{NH}_{3}$ fixed by $\mathrm{H}_{3} \mathrm{BO}_{3}$ was titrated with $\mathrm{HCl}(0.02$ $\mathrm{N})$ until a slightly pink color was obtained. The percentage of $\mathrm{N}$ in the sample was calculated using the following formula:

$$
\% \mathrm{~N}=\frac{\mathrm{VXF}}{\mathrm{A}}
$$

Where:

$\mathrm{V}=\mathrm{HCl}$ volume $(0.02 \mathrm{~N})$

$\mathrm{A}=$ Sample weight $(\mathrm{g})$

$\mathrm{F}=$ Each $\mathrm{mL}$ of $\mathrm{HCl}(0.02 \mathrm{~N})$ is equivalent to $0.28 \mathrm{mg}$ of N.

\section{Statistical analysis}

Statistical analysis was performed using the SPSS v24 computer program. All data were verified for normality, using the KolmogorovSmirnov test and for the homogeneity of variances the Levene test was used. To know the effect of the PF, PS of vegetative and reproductive structures of the bean plant and Nitrogen content for each variety, a comparison test of two samples (T-test) was performed (Dytham, 2011). 


\section{Results and Discussion}

During the first 40 DDS there was a rapid increase in the AF of the two bean varieties "BV" and "BW". In this period, the growth rate of the $\mathrm{AF}$ in the "BW" variety was higher $(28.3 \mathrm{~cm} 2 \mathrm{~d}$ 1) than that recorded in "BV" $(23.3 \mathrm{~cm} 2 \mathrm{~d}-1)$; as a consequence, the variety of yellow pods ("BW") reached a greater surface area of foliage in this period. After 40 and up to 70 DDS, the $\mathrm{AF}$ of the "BW" variety tended to remain constant, while in the "BV" variety it continued to increase at a reduced rate (Figure 1).

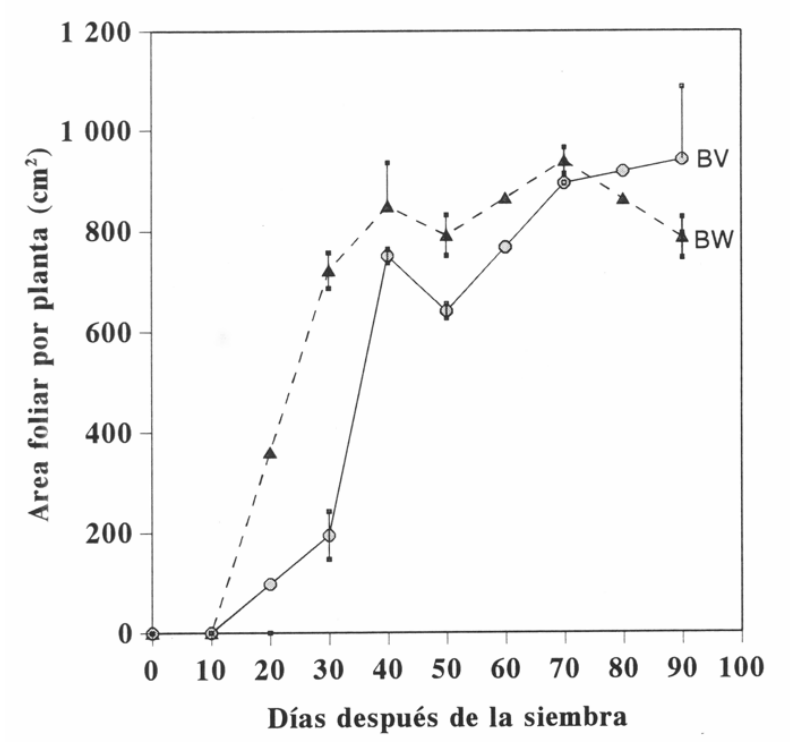

Graphic 1 Foliar area during the development of bean plants $(\mathrm{n}=4)$ in the varieties "BV" (green pods) and "BW" (yellow pods)

Under greenhouse conditions, the flowering phenophase in the "BV" and "BW" varieties began at 36-37 DDS and lasted 10 to 12 days. The process of formation of fruits and seeds extended the following 35 days, to end when the physiological maturity of the pod occurs, showing these the classic "yellowing" of the pericarp, the drying of the pod and the change to black color of the seeds.

During the first 30 DDS, the accumulation of PF was restricted to vegetative structures. At the beginning of the formation of flowers and fruits (36-37 DDS), these organs began to gain biomass until representing approximately $40 \%$ of the total PF in "BW" and $30 \%$ in "BV", so that the vegetative structures in both varieties began to reduce their relative contribution, particularly in the range of 50 to 60 DDS, which corresponds to the stage of seed filling, in which these structures accumulate starch and proteins.
Between 60-90 DDS, the "BV" variety continued to reduce although slowly the proportion of $\mathrm{PF}$ in the vegetative organs, while increasing that of the reproductive ones, while in the "BW" variety the opposite occurred. This suggests that pods of the "BW" variety stop receiving water and solutes at $60 \mathrm{DDS}$, while the "BV" variety still maintains a functional vascular connection.

Although both bean varieties showed a sigmoidal kinetics of biomass accumulation throughout the development of the plant (Graphic 2), the PS accumulation rate during the first 30 DDS was higher in the "BW" variety than in "BV", Which apparently is due to the fact that the first variety surpassed the second in growth of the AF in that same period. However, although the "BV" variety presented a slow onset of PS accumulation, between 30 and 70 DDS its biomass growth rate $\left(5.1 \mathrm{~g} \mathrm{~d}^{-1}\right)$ was double that of "BW" $\left(2.1 \mathrm{~g} \mathrm{~d}^{-1}\right)$ between 30 and 80 DDS. The latter indicates that the "BV" variety has a more efficient $\mathrm{AF}$ than that of "BW" after 30 DDS, that is, during the filling of the pods.

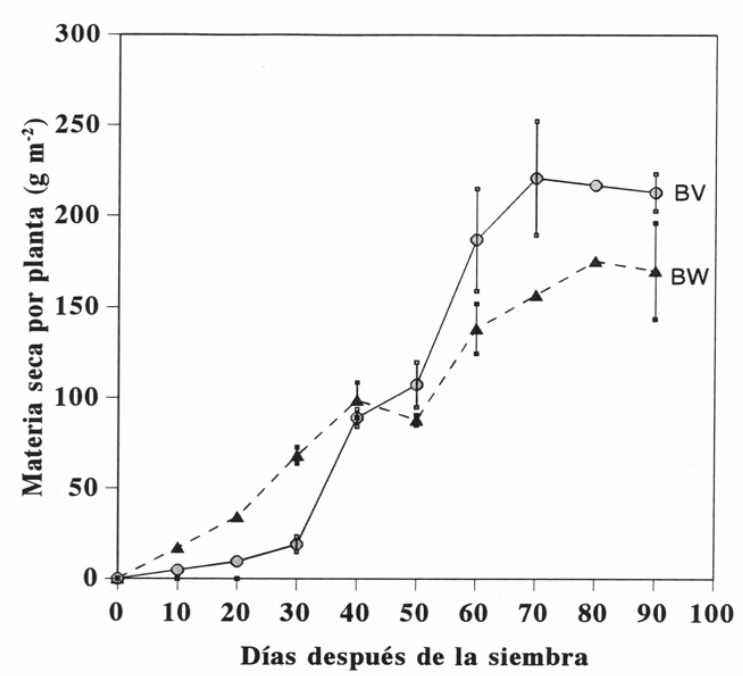

Graphic 2 Biomass accumulation per unit area in bean plants $(\mathrm{n}=4)$ in the varieties "BV" (green pods) and "BW" (yellow pods)

In the vegetative organs the same varietal differences were observed as in total PS; that is, "BW" accumulated higher PS in the first 30 DDS; subsequently the pattern is reversed. The leaves are the vegetative organs with the greatest biomass throughout the cycle, except at the end, when they are matched by the stems. 
In the "BV" variety, the leaves showed their maximum accumulation rate of PS between 30 and 70 DDS (2.97 $\mathrm{g} \mathrm{d}-1$ ), while "BW" the rate was $1.5 \mathrm{~g} \mathrm{~d}-1$ between 10 and 40 DDS In the stem that includes the branches, the accumulation of biomass was lower than in the leaves during the initial stages of development. Up to 40 DDS the "BW" variety showed a rate of $0.81 \mathrm{~g} \mathrm{~d}-1$; subsequently this variety tended to remain constant. In contrast, the "BV" variety showed a different behavior between 30 and 90 DDS (0.80 g d-1). The petioles and petioles presented a pattern similar to that of leaves and stems. In the "BV" variety between 30 and 70 DDS, the rate of increase in both structures was $0.56 \mathrm{~g} \mathrm{~d}^{-1}$, then descend. In the case of "BW" between 10 and 40 DDS, the accumulation was $0.32 \mathrm{~g} \mathrm{~d}^{-1}$.

On the other hand, the reproductive organs showed growth of 50 to 90 DDS, stage in which the filling of pods occurs, so that they accumulate more biomass than any of the vegetative organs. The "BV" variety exhibited a rate of $2.4 \mathrm{~g} \mathrm{~d}^{-1} ; 25 \%$ higher than that registered in the "BW" variety $\left(1.7 \mathrm{~g} \mathrm{~d}^{-1}\right)$. It should be noted that the accumulation of PS in the pods continued until 90 DDS, in both varieties. In the last 20 days (70-90 DDS), the leaves of the "BV" variety lost $23 \%$ of their maximum accumulated biomass and the petioles $5.8 \%$, which is reflected in an increase $(29 \%)$ registered in the reproductive parts.

In the "BW" variety, during the range of 50 to $60 \mathrm{DDS}$, the leaves showed a decrease of $9.5 \%$, the stem $8.16 \%$ and the petiole $3.75 \%$, while in the pods there was a PS gain of $21.4 \%$. These data reveal that during the development of the fruits of the beans, these organs become the main force of demand for photoassimilates, which they require for breathing, as well as loading the storage cells in the cotyledons (Kozlowsky, 1992). Other authors (Geiger, Shieh, 1988; Geiger et al., 1989), consider the beginning of the reproductive development of beans as a fundamental factor in source-demand relations, since it modifies the distribution of carbon by allocating much of the energy that occurs in the plant or that is stored in the vegetative organs to the reproductive structures. In this regard, various authors (Choe, Thimann, 1975.
Thomas, Stoddart, 1980; Smart, 1994), have indicated that the export of dry matter from the leaves is probably due to a manifestation of the beginning of the process of foliar senescence, in the which energy reserves are hydrolyzed and the products of this catabolism (amino acids, amides and other soluble metabolites) are mobilized to other parts of the plant, such as the stem. This translocation process was favored to a greater extent in the "BV" variety than in "BW". In this work it was observed that the distribution of carbon between the vegetative and reproductive organs changed considerably in both varieties during their biological cycle.

According to the percentages of biomass assigned to the different organs of the plant (Table 1 and 2), it is inferred that the leaves supplied most of the photoassimilates required by the reproductive structures. These results coincide with the works carried out by Lucas et al., 1976 where it is reported that in beans the axial part of the leaf is the primary source of photoassimilates to the pods.

\begin{tabular}{|r|r|rrr|r|}
$\begin{array}{c}\text { Days after } \\
\text { planting }\end{array}$ & \multicolumn{1}{c|}{$\begin{array}{c}\text { Dry } \\
\text { weight } \\
\text { plant } \\
\text { (g) }\end{array}$} & \multicolumn{4}{|c|}{$\begin{array}{c}\text { Percentage of accumulated dry } \\
\text { weight }\end{array}$} \\
\hline 30 & 0.86 & 63.43 & 25.28 & 11.27 & --- \\
\hline 40 & 4.03 & 55.70 & 28.89 & 12.72 & 2.63 \\
\hline 50 & 4.85 & 51.56 & 30.44 & 11.06 & 6.91 \\
\hline 60 & 8.46 & 47.29 & 23.11 & 10.57 & 19.0 \\
\hline 70 & 9.99 & 45.89 & 22.52 & 11.20 & 20.36 \\
\hline 80 & 9.81 & 34.35 & 22.26 & 8.46 & 34.90 \\
\hline 90 & 9.63 & 22.81 & 22.0 & 5.72 & 49.45 \\
\hline
\end{tabular}

Table 1 Dry matter accumulated in the plant $(n=4)$ of the variety "BV" and the percentages of accumulation in its different components at different ages

\begin{tabular}{|c|c|c|c|c|c|}
\hline \multirow[t]{2}{*}{$\begin{array}{c}\text { Days after } \\
\text { planting }\end{array}$} & \multirow{2}{*}{$\begin{array}{c}\text { Dry } \\
\text { weight } \\
\text { plant } \\
\text { (g) }\end{array}$} & \multicolumn{4}{|c|}{$\begin{array}{c}\text { Percentage of accumulated dry } \\
\text { weight }\end{array}$} \\
\hline & & Leaf & Stem & Petioles & Pods \\
\hline 30 & 3.09 & 64.12 & 22.88 & 12.97 & --- \\
\hline 40 & 4.47 & 56.60 & 28.54 & 12.05 & 2.77 \\
\hline 50 & 3.97 & 51.43 & 29.38 & 11.04 & 8.09 \\
\hline 60 & 6.25 & 41.97 & 21.22 & 7.29 & 29.48 \\
\hline 70 & 7.93 & 32.39 & 21.61 & 6.51 & 39.46 \\
\hline 80 & 8.76 & 31.55 & 23.93 & 6.11 & 38.38 \\
\hline 90 & 9.60 & 30.72 & 26.25 & 5.72 & 37.30 \\
\hline
\end{tabular}

Table 2 Dry matter accumulated in the plant $(n=4)$ of the "BW" variety and the percentages of accumulation in its different components at different ages

Another important aspect to note is that bean plants of the "BV" and "BW" varieties are of determined growth, in which vegetative development stops during the formation of reproductive structures and there is little overlap between vegetative and reproductive phases. 
In this study, the reproductive phase was characterized by the exclusive presence of demands in the reproductive organs, thus avoiding competition for assimilated with aerial vegetative organs. This facilitates the analysis of the source-demand relationship in this type of species, in contrast to those of undetermined habit in which a strong competition between vegetative and reproductive demands is established in the same period of development (Jeuffroy, Warembourg, 1991).

According to Durigon et al., (2019) the monitoring of flowering and pod formation is important to assess the vigor of the plants. In this study, in the pods of both varieties two stages in the development are distinguished, the first one occurs from the antecedent to the first 14 DDA and is characterized by an exponential longitudinal growth where the "BV" variety showed a rate of $1.0 \mathrm{~cm} \mathrm{~d}-1$ and "BW" of 0.92 cm d-1, accompanied by the development of the pericarp (Graphic 3). After the 14 DDA, the lengthening ceased, coinciding with the beginning of the development of the seeds during which an active accumulation of reserves and a rapid increase of PS occurs (Geiger et al., 1989; Jeuffroy, Warembourg, 1991).

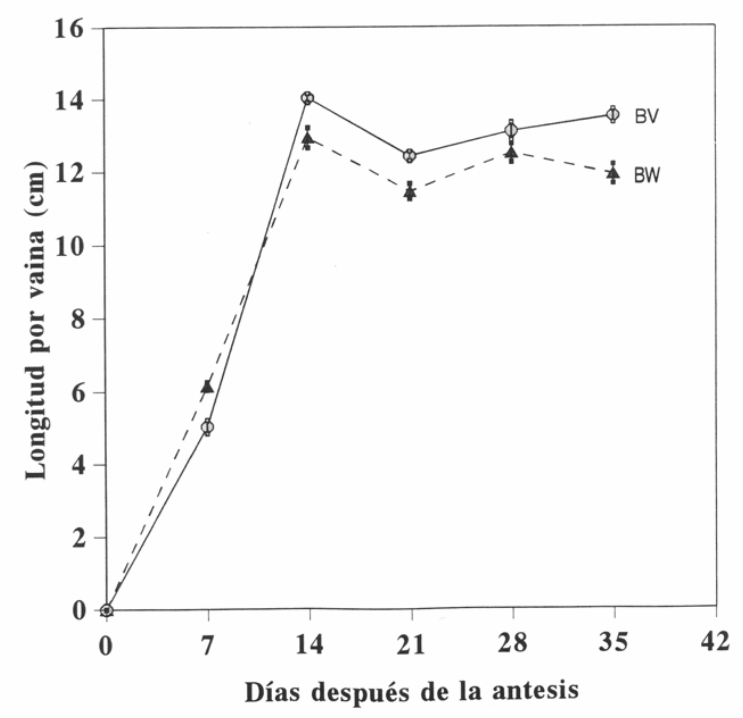

Graphic 3 Longitudinal growth of the bean pod $(n=10)$ from the anterior to physiological maturity in the varieties "BV" (green pods) and "BW" (yellow pods)

During the first 7 days, the increase in PF was relatively small, being greater in the variety "BW" $(\mathrm{P}<0.001)$, which is attributed to the fact that during these first days the growth of the sheath occurs through a Active cell division. Bean pods accumulated most of their FP from 7 to $14 \mathrm{DDA}$, where a higher cumulative rate $(0.7$ $\mathrm{g} \mathrm{d}-1 ; \mathrm{P}<0.01)$ occurred in the "BV" variety, than in the "BW" variety $(0.5 \mathrm{~g} \mathrm{~d}-1)$.
During this period, cell elongation is presented (Geiger et al., 1989). This combination of division growth and cell elongation is common in most succulent fruits during development (Coombe, 1976; Zanchin et al., 1994). After the 14 DDA there was a gradual decrease in the pericarp $\mathrm{PF}$ in both varieties (Graphic 4 A and B; P> 0.05), which is only due to the progressive loss in water content, since there was no reduction in the PS of these organs. The beginning of the decrease in the PF content of the pericarp coincides with the beginning of the exponential increase in the PF of the seeds.

Taking these results into consideration, it can be said that the decrease in PF in the pericarp of the pod contributed to the increase in the PF of the seeds, which is probably attributed in large part to the water transferred by the tissues of the pericarp. Note that this increase is continuous up to $35 \mathrm{DDA}$ in the seeds of the "BV" variety but not in "BW", since in the latter the profit at 28 DDA ceases. The "BV" variety showed a higher rate of accumulation of PF in the seed $(0.19 \mathrm{~g} \mathrm{~d}$ 1) than the "BW" variety $(0.14 \mathrm{~g} d-1)$. In addition, it was observed that the gain of PF in the seeds was slower, although it lasted longer (21 days), than the one recorded in the pericarp, in which it occurred rapidly but only lasted 7 days.

This behavior was similar to that reported in other bean varieties (Oliker et al, 1978). As in PF, during the first 7 days, the increase in PS was relatively small, being greater in the variety "BW" $(\mathrm{P}<0.001)$, From 7 to 14 DDA, the variety "BV" had a greater PS increase rate than " $\mathrm{BW}$ " $(\mathrm{P}<0.01)$. From that date, the same dry matter accumulation rate was maintained in both varieties (Graphic 5 A and B; $\mathrm{P}>0.05)$.

It is important to note that the exponential increase in biomass in the seed was not accompanied by a decrease in the PS of the pericarp, so it follows that the walls of the pods were not an important source of carbon for the developing seeds, which coincides with that reported by Oliker et al., (1978). Similarly, Lucas et al. (1976), Flinn et al. 1977 and Thorne (1979) showed that a large proportion of the nutrients required by developing legume seeds comes from the translocation of assimilates originating in vegetative organs and that the fruit's reserves provide a limited supply.

NERI-LUNA, Cecilia, VILLARREAL-RUIZ, Luis, HUERTAMARTÍNEZ, Francisco Martín and MUÑOZ-URIAS Alejandro. Phenology and biomass distribution pattern in two varieties of common bean (Phaseolus vulgaris L.). Journal of Natural and Agricultural Sciences. 2019 
In contrast, Crookston et al. (1974) consider the pericarp as a storage organ for assimilates formed in the leaves. In other legumes such as soybeans, this temporary storage allows nutrients to become useful forms and contribute to the growth of seeds in a short period (Thorne, 1979). There are even studies in which it has been shown that the pericarp of bean pods contributes to the nutrients that translocate the seeds (Peña-Valdivia, Ortega-Delgado, 1991). According to the results, during the first 14 DDA, the pericarp of the sheath is constituted as the main demand for assimilates. After this period and until the end of the development of the fruit, the seed assumes this function.

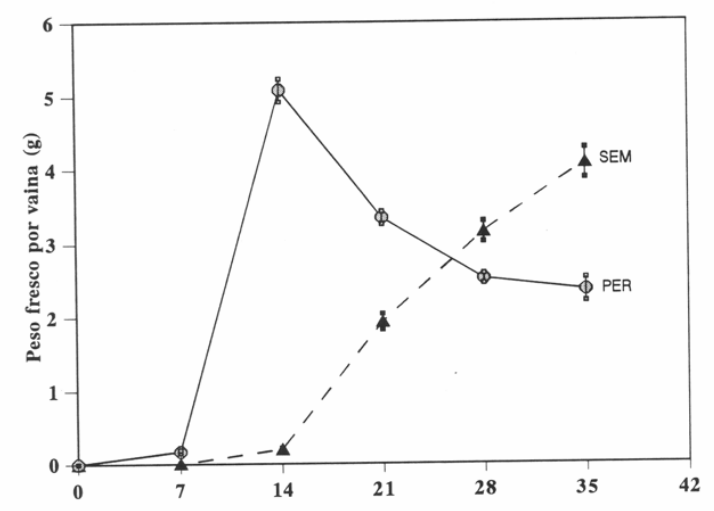

A

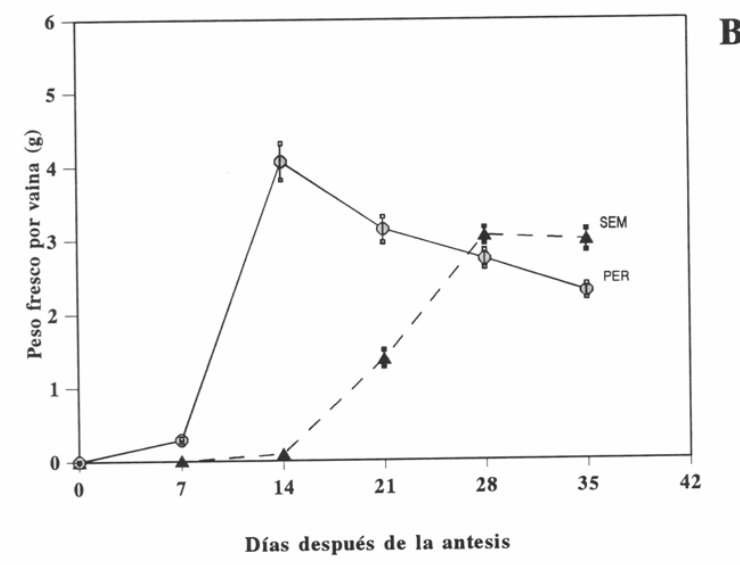

Graphic 4 Accumulation of fresh weight in the pericarp (PER) and seeds (SEM) during the development of the pods $(\mathrm{n}=10)$ of the beans in the varieties "BV" $(\mathrm{A})$ and "BW" (B)

In the pericarp of the pods of both varieties, the highest $\mathrm{N}$ content was recorded at 7 DDA, subsequently showing a gradual reduction to 35 DDA (Graphic $6 \mathrm{~A}$ and $\mathrm{B}$ ). Such decrease was faster in "BV" $(2.2 \mathrm{~g} \mathrm{~d}-1)$, than in "BW" (1.8 g d-1).
In contrast, the seeds showed an increase in their $\mathrm{N}$ content, which was more pronounced in the "BV" variety than in "BW", since in the latter the content was stable during the first 21 DDA, date on which began the accumulation of $\mathrm{N}$ in the seeds, which ceased at 28 DDA, while the "BV" variety continued until 35 DDA.
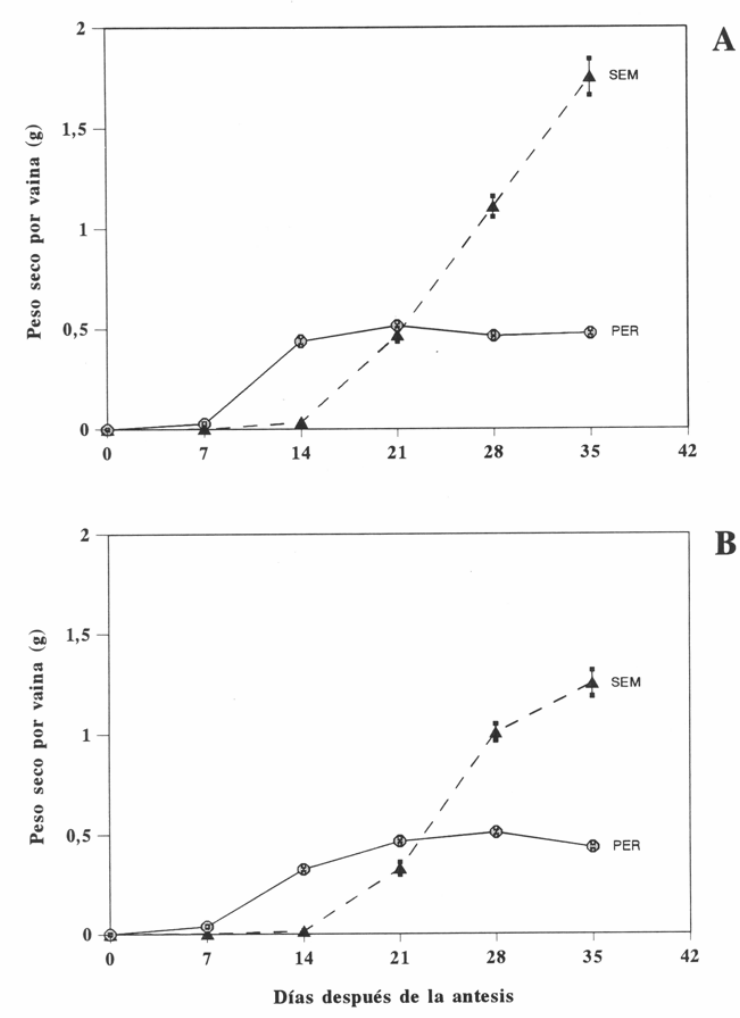

Graphic 5 Dry weight accumulation in the pericarp (PER) and seeds (SEM) during the development of the bean pods $(\mathrm{n}=10)$ in the "BV" $(\mathrm{A})$ and "BW" $(\mathrm{B})$ varieties

According to these observations, the increase in the content of this essential nutrient coincides with the period of simultaneous filling and accumulation of starch in the seeds (Geiger et al., 1989). The previous results make it possible to assume that during the initial phases of fruit growth, the pericarp was constituted as the main demand for $\mathrm{N}$ in the pod and that later, during the growth of the seeds, the pericarp was constituted as a source of that nutrient. 

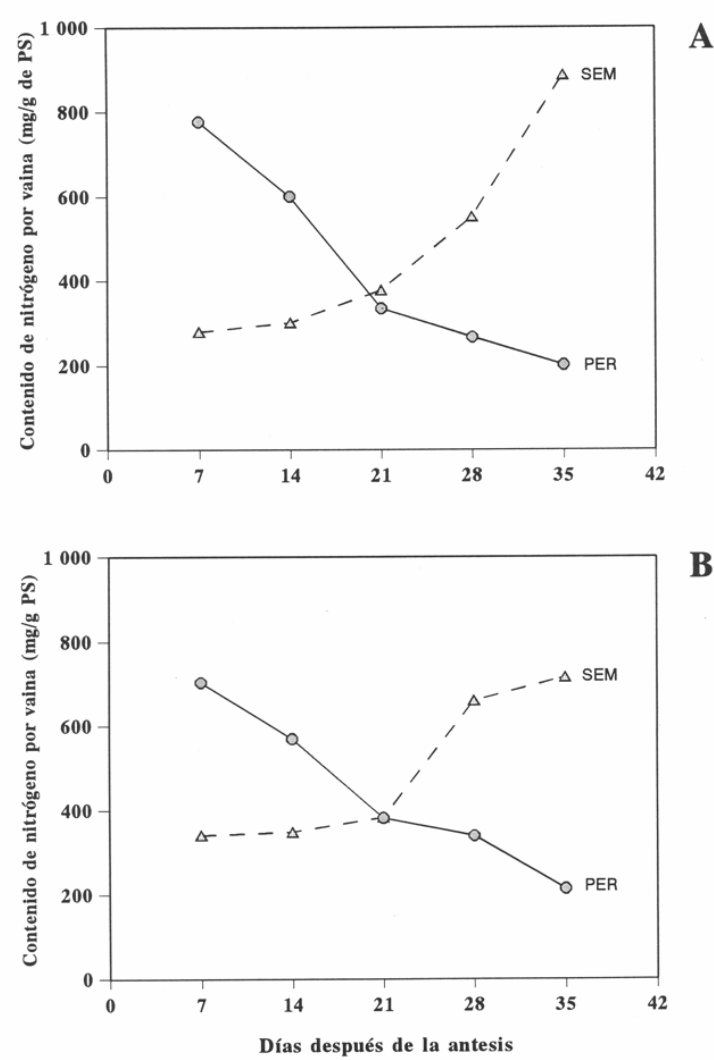

Graphic 6 Variation in the content of nitrogen in the pericarp (PER) and seeds (SEM) during the development of bean pods $(\mathrm{n}=10)$ in the varieties "BV" $(\mathrm{A})$ and "BW" (B)

It is common that in monocarpic plants, as in the case of beans, an important part of the supply of $\mathrm{N}$ to the reproductive structures comes from the vegetative organs (root, stem and leaves), since they function as a store for photoassimilates and nitrogen compounds in the early stages of plant development; such reserves are translocated to the inflorescences and pods and once they begin their development (Granados et al., 1987). In other legumes in which the distribution of the external supply of $15 \mathrm{~N}$ has been evaluated during the development of the plant, it has been found that this element initially accumulates in the leaves and then is transported to the pericarp of the pods, and finally to the seeds (Oliker et al., 1978).

In this work it was observed that the pericarp of the bean pod of both varieties acted as an organ of water transfer and $\mathrm{N}$ of the vegetative organs to the developing seeds, coinciding with the investigations carried out by Fountain et al. (1989).
This translocation was more efficient in the "BV" variety than in "BW", which shows differences in the strength of demand of the seed between both varieties, which is finally reflected in accumulated biomass and final $\mathrm{N}$ content and perhaps protein in the grain, the latter being important quality parameters to characterize varieties with different types and growth habits (Granados et al., 1987). Finally, it is important to consider that the knowledge of the mechanisms of translocation of photosynthetic products between harvested and non-harvested parts in commercial species, constitutes a key point in programs aimed at improving the production of these plants.

This would allow manipulating the interactions established between the source and the demand, in order to achieve quantitative and qualitative changes that are reflected in the increase in the harvest index and in productivity. In other words, studies involving the mechanisms of translocation and storage of $\mathrm{N}$ acquire great importance because the seeds of beans constitute a main source of protein in the human diet, especially in Mexico (Lara-Flores, 2015; Salinas- Ramírez et al., 2008).

\section{Conclusions}

During the first 30 DDS the accumulation rate of dry matter in both varieties was directly related to the increase in AF. After this date, the "BV" variety showed a more efficient $\mathrm{AF}$. The beginning of the development of flowers and fruits was a fundamental factor in the sourcedemand relations in the bean plant, since it modified the distribution of water and carbon between the vegetative and reproductive organs.

The leaves supplied most of the photoassimilates required by the reproductive structures. In the fruits of beans, during the first 14 DDS the pericarp of the pod was constituted as the main demand for water, nutrients and photoassimilates; subsequently, the pericarp of both varieties acted as an organ of water and nitrogen transfer, as well as a partial source of carbon during the initial phases of seed formation.

\section{References}

Coombe BG. 1976. The devolopment of fleshy fruits. Ann. Rev. Plant Physiolo. 27: 507-428. 
CIAT. 1982. Etapas de desarrollo de la planta de frijol común. Guía de estudios. Centro Internacional de Agricultura Tropical. Cali, Colombia. Pp. 18-20.

Choe H, Thimann KV. 1975. The metabolism of oat leaves during senescence. Plant Physiol. 55: 828-834.

Crookston RK, O’Toole J, Ozbun JL. 1974. Characterization of the bean pod as a photosynthetic organ. Crop Sci. 14: 708-712.

Durigon A, Evers J, Metselaar K, van Lier Q de J. 2019. Water stress permanently alters shoot architecture in common bean plants. Agronomy 9:160 doi:10.3390/agronomy9030160

Dytham C. 2011. Choosing and using statistics: a biologist's guide. 3rd Edition. Blackwell Publishing. United Kingdom. 292 p.

Esquivel-Esquivel G, Acosta-Gallegos JA, Rosales-Serna R, Pérez-Herrera P, HernándezCasillas JM, Navarrete-Maya R, MuruagaMartínez JS. 2006. Productividad y adaptación del frijol ejotero en el Valle de México. Revista Chapingo Serie Horticultura 12(1): 119-126.

FIRA. 2016. El frijol. Panorama Agroalimentario. Dirección de Investigación y Evaluación Económica Sectorial. 31 p.

Flinn AM, Atkins CA, Pate JS. 1977. Significance of photosynthetic and respiration exchanges in the carbon economy of the developing pea fruit. Plant Physiol. 60: 412-418.

Fountain DW, Outred HA, Holdsworth JM, Thomas RG. 1989. Seed development in Phaseolus vulgaris L cv. Seminole. Plant Physiol. 89: 333-340.

Geiger DR, Shieh WJ. 1988. Analysing partitioning of recently fixed and reserve carbon in reproductive Phaseolus vulgaris L. plants. Plant, Cell and Environment 11: 777-783.

Geiger DR, Shieh WJ, Saluke RM. 1989. Carbon partitioning among leaves, fruits and seeds during development of Phaseolus vulgaris L. Plant Physiol. 91: 291-297.

Gebeyehu Y S. 2019. Evaluation of growth performance of common bean (Phaseolus vulgaris L.) genotypes during two phenological phases. World Scientific News 128(2): 171-181.

ECORFAN® All rights reserved
Granados AR, Ortega-Delgado ML, Zárate G. 1987. Influencia del peso seco y contenido de nitrógeno de los órganos de la planta en el rendimiento y contenido de proteína del grano de frijol Phaseolus vulgaris L. Chapingo 54-55: 4752.

Jeuffroy MH, Warembourg FR. 1991. Carbon transfer and partitioning between vegetative and reproductive organs in Pisum sativum L. Plant Physiol. 97: 440-448.

Kozlowski TT. 1992. Carbohydrate sources and sinks in woody plants. Bot. Rev. 58(2): 107-222. Lara-Flores M. 2015. El cultivo del frijol en México. Revista Digital Universitaria. 16 (2): 111.

Lucas EO, Milbourn GM, Whitford PN. 1976. The transcolation of ${ }^{14} \mathrm{C}$ photosynthate from leaves and pods in Phaseolus vulgaris. Ann. Appl. Biol. 83: 291-297.

Miranda CS. 1990. Identificación de las especies cultivadas del género Phaseolus. Centro de Genética. Colegio de Postgraduados. Montecillo, Edo. De México. 20 p.

Oliker M, Poljakoff-Mayber A, Mayer AM. 1978. Changes in weight, nitrogen accumulation, respiration and photosynthesis during growth and development of seeds and pods of Phaseolus vulgaris. Amer. J. Bot. 65: 366-371.

Padilla-Chacón D, Peña-Valdivia CB, GarcíaEsteva A, Cayetano-Marcial MI and KohashiShibata J. 2019. Phenotypic variation and biomass partitioning during post-flowering in two common bean cultivars (Phaseolus vulgaris L.) under water restriction. South African Journal of Botany 121: 98-104.

Peña-Valdivia CB, Ortega-Delgado ML. 1991. Non-structural carbohydrate partitioning in Phaseolus vulgaris after vegetative growth. J. Sci. Food Agric. 55: 563-577.

Robles SR. 1990. Producción de Granos y Forrajes. 5a. Edición. Editorial Limusa. México, D.F. 664 p.

Salinas-Ramírez N, Escalante-Estrada JA, Rodríguez-González MT, Sosa-Montes E. 2008. Rendimiento y calidad nutrimental de frijol ejotero (Phaseolus vulgaris L.) en fechas de siembra. Rev. Fitotec. Mex. 31 (3): 235 - 241.

NERI-LUNA, Cecilia, VILLARREAL-RUIZ, Luis, HUERTAMARTÍNEZ, Francisco Martín and MUÑOZ-URIAS Alejandro. Phenology and biomass distribution pattern in two varieties of common bean (Phaseolus vulgaris L.). Journal of Natural and Agricultural Sciences. 2019 
Smart CM. 1994. Gene expression during leaf senescence. New Phytol. 126: 419-448.

Thorne JH. 1979. Assimilate redistribution from soybean pod walls during seed development. Agronomic Journal 71: 812-816.

Thomas H, Stoddart JL. 1980. Leaf senescence. Ann. Rev. Plant. Phisiol. 31: 83-111.

Wallace L, Arkwazee H, Vining K, Myers JR. 2018. Genetic Diversity within Snap Beans and Their Relation to Dry Beans. Genes 9: 587; doi:10.3390/genes9120587

Zanchin AC, Bonghi C, Casadoro G, Ramina A, Rascio N. 1994. Cell enlargement and cell separation during peach fruit development. Int. J. Plant Sci. 155: 49-56. 